\title{
Growth and Correlation with Weather Parameters as Affected by Transplanting Time and Different Varieties of Paddy (Oryza sativa L.)
}

\begin{abstract}
Background: Time of planting is the most important factor in influencing the yield of the crop. Performance of genotype entirely depends upon the time of planting. For obtaining higher paddy production study of crop for transplanting time and different varieties concerning weather parameters are very necessary.

Methods: Experiment was laid out in a split-plot design with three replications at Agriculture Research Station Farm, Vadgaon-Maval, Tal-Maval, Dist-Pune (M.S.) during Kharif, 2013 to study effect of transplanting time on different varieties of paddy concerning weather parameters. 48 treatment combinations were comprised of 4 transplanting times viz., $26^{\text {th }}, 28^{\text {th }}, 30^{\text {th }}$ and $32^{\text {nd }}$ meteorological weeks and four varieties viz., VDN-3-51-18, VDN-99-29, IET-13549 and RDN-99-1.

Result: Transplanting of Kharif paddy during $28^{\text {th }} \mathrm{MW}$ improved plant growth. Variety VDN-99-29 recorded significantly higher plant growth. Among the interaction, when the VDN-99-29 variety of paddy was transplanted during $28^{\text {th }}$ MW produced significant effect on plant growth. Correlation indicated that maximum temperature, bright sun hour and growing degree days showed significant and negative co-relationship with plant-growth, minimum temperature, $\mathrm{RH}-\mathrm{I}$ and $\mathrm{RH}-\mathrm{Il}$ showed positive and significant correlation with growth.
\end{abstract}

Key words: Correlation, Growth characters, Paddy varieties, Transplanting time, Weather parameters.

\section{INTRODUCTION}

Paddy has been the staple food for more than 60 per cent of the world population, providing energy for about $40 \%$ of the world population where every third person on earth consumes rice every day in one form or other (Virdia and Mehta, 2009). Therefore, crop paddy (Oryza sativa L.) is an important crop that is extensively grown in tropical and subtropical regions of the world. Global demand for food is rising because of population growth, increasing affluence and changing dietary habits. The UN/FAO forecasts that global food production will need to increase by over $40 \%$ by 2030 and $70 \%$ by 2050 . Yet globally, water is anticipated to become scarce and there increasing competition for land, putting added pressure on agricultural production. Besides, climate change will reduce the reliability of the food supply through altered weather patterns and increased pressure from pests and diseases.

Transplanting time and sowing date significantly influenced on growth and yield of rice crops, it has been studied by the number of research workers from various parts of India and abroad. The transplanting time and sowing time of the rice crop are important for three major reasons. Firstly, it ensures that vegetative growth occurs during a period of satisfactory temperatures and total sunshine hours. Secondly, the optimum transplanting time and sowing time for each cultivar ensure the cold-sensitive stage occurs when the minimum night temperatures are historically the warmest. Thirdly, transplanting and sowing on-time guarantees that grain filling occurs when milder autumn temperatures are more likely, hence good grain quality is achieved. Results
Agricultural Research Station, Vadgaon-Maval, Pune-412 106, Maharashtra, India.

Corresponding Author: Sudarshan M. Shende, Department of Agronomy, Mahatma Phule Krishi Vidyapeeth, Rahuri-413 722, Maharashtra, India. Email: sudarshanshende77@gmail.com

How to cite this article: Shinde, S.A., Kashid, N.V. and Shende, S.M. (2022). Growth and Correlation with Weather Parameters as Affected by Transplanting Time and Different Varieties of Paddy (Oryza sativa L.). Agricultural Science Digest. DOI: 10.18805/ ag.D-5499.

Submitted: 25-09-2021 Accepted: 03-01-2022 Online: 14-02-2022

from different studies revealed that the maximum yield potential of a rice crop is usually achieved when the crop is exposed to the most appropriate temperature range, which can be controlled by transplanting sowing at the proper time. Recently weather variability being considered one of the major factors of inter-annual variability of crop growth and yield in all environments besides rainfall, temperature and bright sunshine hours also have been bearing on crop growth and development as well as yield response of different species to different environments can be quite different. The shift in sowing dates directly influences both the thermo and photoperiod and consequently has great impact on the phasic development and partitioning of dry matter (Patel et al., 2019). Timely planting, using proper plant protection measures and providing irrigation at right time was the most desired practices at the farmers own level for yield improvement by rice growers (Grover, 2013). 
Growth and Correlation with Weather Parameters as Affected by Transplanting Time and Different Varieties of Paddy...

The early-planted photoperiod-sensitive rice varieties go through a lag vegetative phase during which increases height, as well as biomass, making them prone to lodging during the grain-filling stage. Adjustment in the transplanting time, therefore, enables the plants to take advantage of natural conditions favourable for growth. Yoshida (1993) reported that rice plants require a particular temperature for phenological responses such as panicle initiation, flowering and panicle exsertion from flag leaf sheath and maturity and these responses are very much influenced by the planting dates in the transplanted paddy. Moreover, the genetic variability and the potentiality of the genotypes were expressed differently due to planting at different dates. The optimum planting time of transplanted Kharif paddy is in July but transplanting is sometimes delayed due to various physical and socio-economic factors. Late planting exposes the reproductive phase as well as phonological events of the crop to unfavourable temperature regimes, thereby causing high spikelet sterility and poor plant growth. However, optimum rice planting dates are regional and vary with location and genotypes (Bruns and Abbas, 2006). Chowdhury et al., (2000) reported that grain and straw yields gradually decreased when rice is planted after $10^{\text {th }}$ of August transplanting. Islam (1986) concluded that the time between 15 July and 20 August was optimum for transplanting of Kharif rice, especially the photosensitive varieties. As the timing of planting influenced the growth and yield of transplanted Kharif rice genotypes, the present study was conducted to find optimum transplanting time of four selected high-yielding varieties for the Kharif season.

\section{MATERIALS AND METHODS}

An experiment entitled, "Effect of transplanting time on different varieties of paddy concerning weather parameters" was carried out in a split-plot with sixteen treatment combinations and three replications. The treatment comprising four transplanting times viz., $\mathrm{T}_{1}: 26^{\text {th }} \mathrm{MW}\left(24^{\text {th }}\right.$ June to $30^{\text {th }}$ June), $\mathrm{T}_{2}: 28^{\text {th }} \mathrm{MW}$ ( $8^{\text {th }}$ July to $14^{\text {th }}$ July), $\mathrm{T}_{3}: 30^{\text {th }}$ MW (22 nd July to $28^{\text {th }}$ July), $T_{4}: 32^{\text {nd }} \mathrm{MW}$ ( $5^{\text {th }}$ August to $11^{\text {th }}$ August) as main plot treatment and four paddy varieties viz., $V_{1}$ : VDN-3-51-18 (Indrayani), $V_{2}$ : VDN-99-29 (Phule Samruddhi), $V_{3}$ : IET 13549 (Bhogawati), $V_{4}$ : RDN-99-1 (Phule Radha) as sub-plot treatment during Kharif, 2013 at ARS Farm, Vadgaon-Maval, Tal-Maval, Dist-Pune (M.S.), India.

Experimental field soil was clay loam, normal in reaction $(\mathrm{pH} 7.1)$, having EC $0.32 \mathrm{dS} \mathrm{m}^{-1}$ and $\mathrm{OC}$ was medium $(0.53 \%)$, low in available nitrogen (162.67 $\left.\mathrm{kg} \mathrm{ha}^{-1}\right)$, high in available phosphorus (29.56 kg ha-1) and high in available potassium (467.00 kg ha-1). Crop was transplanted according to different treatments of transplanting time along with different varieties. The required quantity of fertilizer was given in the form of Urea-DAP briquette and MOP as basal dose. Gross plot size was $2.95 \mathrm{~m} \times 2.15 \mathrm{~m}$ and net plot size was $2.65 \mathrm{~m} \times 1.35 \mathrm{~m}$. Paddy seedlings were raised by line sowing of seeds on the nursery bed. First, second, third and fourth sowing on nursery bed was done on $10^{\text {th }}$ June, $25^{\text {th }}$ June, $9^{\text {th }}$ July and $22^{\text {nd }}$ July, respectively and seedlings were transplanted at $15-25 \mathrm{~cm} \times 15-25 \mathrm{~cm}$ spacing. For recording observations, five plants were selected randomly from each net plot and marked by fixing pegs near them. All the observations on growth were recorded on these plants. The statistical analysis of split-plot design with 4 replications, 3 main plot treatments and 3 sub-plot treatments were done by standard procedures suggested by Panse and Sukhamate (1967).

\section{RESULTS AND DISCUSSIONS Growth characters of paddy \\ Plant height of paddy $(\mathrm{cm})$}

Mean plant height was significantly influenced by different transplanting times presented in Table 1. The Kharif paddy Table 1: Mean plant height $(\mathrm{cm})$ and mean total number of tillers plant ${ }^{-1}$ as influenced periodically by different treatments.

\begin{tabular}{|c|c|c|c|c|c|c|c|c|c|}
\hline \multirow{3}{*}{ Treatments } & \multicolumn{8}{|c|}{ Plant height } & \multirow{3}{*}{$\begin{array}{r}\text { Number of } \\
\text { tillers plant }{ }^{-1} \\
\text { At harvest } \\
\end{array}$} \\
\hline & \multicolumn{8}{|c|}{ Days after transplanting (DAT) } & \\
\hline & 15 & 30 & 45 & 60 & 75 & 90 & 105 & At harvest & \\
\hline \multicolumn{10}{|l|}{ Main plot: Transplanting times } \\
\hline $\mathrm{T}_{1}: 4^{\text {th }}$ week of June $\left(26^{\text {th }} \mathrm{MW}\right)$ & 26.7 & 42.3 & 54.9 & 69.4 & 79.9 & 81.2 & 81.8 & 82.2 & 14 \\
\hline $\mathrm{T}_{2}: 2^{\text {nd }}$ week of July $\left(28^{\text {th }} \mathrm{MW}\right)$ & 27.6 & 44.1 & 57.1 & 72.6 & 83.5 & 85.2 & 85.7 & 86.2 & 16 \\
\hline $\mathrm{T}_{3}: 4^{\text {th }}$ week of July $\left(30^{\text {th }} \mathrm{MW}\right)$ & 23.4 & 37.4 & 46.8 & 60.1 & 69.1 & 70.5 & 70.8 & 71.3 & 12 \\
\hline $\mathrm{T}_{4}: 2^{\text {nd }}$ week of Aug $\left(32^{\text {nd }} \mathrm{MW}\right)$ & 20.9 & 33.6 & 42.4 & 54.2 & 62.3 & 63.6 & 64.0 & 64.4 & 8 \\
\hline S.Em \pm & 0.56 & 0.79 & 0.77 & 1.01 & 1.15 & 1.11 & 1.12 & 1.11 & 0.28 \\
\hline C.D. at $5 \%$ & 1.97 & 2.80 & 2.73 & 3.55 & 4.06 & 3.93 & 3.96 & 3.91 & 0.84 \\
\hline \multicolumn{10}{|l|}{ Subplot: Paddy varieties } \\
\hline $\mathrm{V}_{1}:$ VDN-3-51-18 (Indrayani) & 25.3 & 40.5 & 52.3 & 70.1 & 80.6 & 82.2 & 82.7 & 83.2 & 14 \\
\hline $\mathrm{V}_{2}:$ VDN-99-29 (Phule Samruddhi) & 28.6 & 45.8 & 59.1 & 73.9 & 84.9 & 86.5 & 87.0 & 87.5 & 17 \\
\hline $\mathrm{V}_{3}:$ IET-13549 (Bhogawati) & 23.4 & 37.1 & 47.9 & 59.9 & 69.0 & 70.4 & 70.8 & 71.2 & 12 \\
\hline $\mathrm{V}_{4}:$ RDN-99-1 (Phule Radha) & 21.2 & 34.1 & 41.93 & 52.4 & 60.3 & 61.5 & 61.9 & 62.2 & 8 \\
\hline S.Em \pm & 0.44 & 0.76 & 1.01 & 1.23 & 1.41 & 1.41 & 1.41 & 1.41 & 0.25 \\
\hline C.D. at $5 \%$ & 1.29 & 2.23 & 2.98 & 3.60 & 4.14 & 4.12 & 4.15 & 4.15 & 1.52 \\
\hline General mean & 24.6 & 39.4 & 50.3 & 64.1 & 73.7 & 75.1 & 75.5 & 76.0 & 13 \\
\hline
\end{tabular}


Growth and Correlation with Weather Parameters as Affected by Transplanting Time and Different Varieties of Paddy...

Table 2: Mean plant height $(\mathrm{cm})$ and mean total number of tillers plant ${ }^{-1}$ as influenced periodically by interaction between transplanting time and varieties.

\begin{tabular}{|c|c|c|c|c|c|c|c|c|c|}
\hline \multirow{3}{*}{$\begin{array}{l}\text { Treatment } \\
\text { combinations }\end{array}$} & \multicolumn{8}{|c|}{ Plant height } & \multirow{3}{*}{$\begin{array}{l}\text { Number of } \\
\text { tillers plant } \\
\text { At harvest }\end{array}$} \\
\hline & \multicolumn{8}{|c|}{ Days after transplanting (DAT) } & \\
\hline & 15 & 30 & 45 & 60 & 75 & 90 & 105 & At harvest & \\
\hline $\mathrm{T}_{1} \mathrm{~V}_{1}$ & 28.2 & 45.1 & 59.1 & 76.9 & 88.9 & 90.2 & 90.8 & 91.3 & 17 \\
\hline $\mathrm{T}_{1} \mathrm{~V}_{2}$ & 29.1 & 46.5 & 61.0 & 81.2 & 93.4 & 95.3 & 95.8 & 96.4 & 17 \\
\hline $\mathrm{T}_{1} \mathrm{~V}_{3}$ & 23.6 & 37.8 & 47.2 & 65.2 & 75.0 & 76.5 & 77.0 & 77.4 & 14 \\
\hline $\mathrm{T}_{1} \mathrm{~V}_{4}$ & 20.3 & 32.5 & 41.7 & 56.7 & 65.2 & 66.5 & 67.0 & 67.5 & 09 \\
\hline $\mathrm{T}_{2} \mathrm{~V}_{1}$ & 29.7 & 47.5 & 62.4 & 78.0 & 89.7 & 90.8 & 91.3 & 91.7 & 19 \\
\hline $\mathrm{T}_{2} \mathrm{~V}_{2}$ & 32.3 & 51.6 & 67.8 & 84.7 & 97.4 & 99.4 & 100.0 & 100.6 & 21 \\
\hline $\mathrm{T}_{2} \mathrm{~V}_{3}$ & 28.0 & 44.7 & 55.9 & 69.8 & 80.3 & 81.9 & 82.4 & 82.9 & 15 \\
\hline $\mathrm{T}_{2} \mathrm{~V}_{4}$ & 24.5 & 39.2 & 50.2 & 62.7 & 72.2 & 73.6 & 74.1 & 74.5 & 11 \\
\hline $\mathrm{T}_{3} \mathrm{~V}_{1}$ & 25.6 & 39.6 & 53.1 & 66.4 & 76.4 & 77.9 & 78.4 & 78.9 & 12 \\
\hline $\mathrm{T}_{3} \mathrm{~V}_{2}$ & 24.8 & 39.6 & 52.6 & 65.8 & 75.7 & 77.2 & 77.6 & 78.1 & 14 \\
\hline $\mathrm{T}_{3} \mathrm{~V}_{3}$ & 21.5 & 34.3 & 41.5 & 51.9 & 59.7 & 60.9 & 61.3 & 61.6 & 10 \\
\hline $\mathrm{T}_{3} \mathrm{~V}_{4}$ & 27.7 & 34.7 & 44.5 & 55.7 & 64.0 & 65.3 & 65.7 & 66.1 & 07 \\
\hline $\mathrm{T}_{4} \mathrm{~V}_{1}$ & 23.1 & 36.9 & 45.0 & 56.3 & 64.7 & 66.0 & 66.4 & 66.8 & 09 \\
\hline $\mathrm{T}_{4} \mathrm{~V}_{2}$ & 24.2 & 38.6 & 46.9 & 58.6 & 67.4 & 68.7 & 69.2 & 69.6 & 11 \\
\hline $\mathrm{T}_{4} \mathrm{~V}_{3}$ & 20.5 & 32.7 & 42.5 & 53.1 & 61.1 & 62.3 & 62.7 & 63.1 & 09 \\
\hline $\mathrm{T}_{4} \mathrm{~V}_{4}$ & 17.4 & 27.7 & 33.2 & 41.5 & 47.7 & 48.7 & 49.0 & 49.2 & 06 \\
\hline S.Em \pm & 1.12 & 1.58 & 1.55 & 2.01 & 2.30 & 2.22 & 2.24 & 2.21 & 0.42 \\
\hline C.D. at $5 \%$ & 3.32 & 4.62 & 4.68 & 6.03 & 6.65 & 6.62 & 6.65 & 8.58 & 1.52 \\
\hline General mean & 24.6 & 39.4 & 50.3 & 64.1 & 73.7 & 75.1 & 75.5 & 76.0 & 13 \\
\hline
\end{tabular}

Table 3: Weekly weather-meteorological data recorded during experiment (June 2013-December 2013).

\begin{tabular}{|c|c|c|c|c|c|c|c|c|c|}
\hline \multirow[t]{2}{*}{$\begin{array}{l}\text { Month and } \\
\text { year }\end{array}$} & \multirow[t]{2}{*}{ M.W. } & \multirow[t]{2}{*}{ Period } & \multicolumn{2}{|c|}{$\begin{array}{c}\text { Mean } \\
\text { Temp. }\left({ }^{\circ} \mathrm{C}\right)\end{array}$} & \multicolumn{2}{|c|}{$\begin{array}{l}\text { R.H. } \\
(\%)\end{array}$} & \multirow{2}{*}{$\begin{array}{c}\text { Rainfall } \\
(\mathrm{mm})\end{array}$} & \multirow{2}{*}{$\begin{array}{c}\text { Rainy } \\
\text { day }\end{array}$} & \multirow{2}{*}{$\begin{array}{c}\text { Bright } \\
\text { Sunshine } \\
\left(\text { hrs day }^{-1}\right)\end{array}$} \\
\hline & & & Max. & Min. & Morn. & Eve. & & & \\
\hline June-2013 & 26 & $24-30$ & 25.8 & 22.4 & 91 & 86 & 65 & 7 & 1.2 \\
\hline \multirow[t]{4}{*}{ July-2013 } & 27 & 01-07 & 26.1 & 22.1 & 91 & 87 & 74 & 7 & 1.1 \\
\hline & 28 & $08-14$ & 24.1 & 21.5 & 91 & 91 & 118 & 7 & 1.3 \\
\hline & 29 & $15-21$ & 24.2 & 21.4 & 91 & 91 & 132 & 7 & 1.1 \\
\hline & 30 & $22-28$ & 24.1 & 21.0 & 91 & 91 & 152 & 7 & 0.8 \\
\hline \multirow[t]{5}{*}{ Aug-2013 } & 31 & $29-04$ & 24.5 & 21.2 & 91 & 88 & 101 & 7 & 1.5 \\
\hline & 32 & $05-11$ & 26.0 & 22.1 & 91 & 84 & 35 & 7 & 2.1 \\
\hline & 33 & $12-18$ & 26.0 & 21.4 & 91 & 84 & 41 & 7 & 1.8 \\
\hline & 34 & $19-25$ & 25.5 & 21.0 & 91 & 81 & 32 & 7 & 1.9 \\
\hline & 35 & $26-01$ & 27.1 & 21.2 & 91 & 83 & 08 & 1 & 5.6 \\
\hline \multirow[t]{4}{*}{ Sept-2013 } & 36 & $02-08$ & 28.5 & 20.8 & 91 & 83 & 11 & 1 & 3.3 \\
\hline & 37 & $09-15$ & 29.5 & 21.7 & 91 & 74 & 107 & 7 & 1.4 \\
\hline & 38 & $16-22$ & 27.0 & 21.4 & 91 & 83 & 29 & 7 & 1.4 \\
\hline & 39 & $23-29$ & 26.2 & 21.1 & 91 & 84 & 09 & 1 & 2.6 \\
\hline \multirow[t]{5}{*}{ Oct-2013 } & 40 & $30-06$ & 28.5 & 21.1 & 91 & 72 & 17 & 1 & 1.8 \\
\hline & 41 & $07-13$ & 28.0 & 19.7 & 91 & 75 & 0 & 0 & 7.7 \\
\hline & 42 & $14-20$ & 29.5 & 21.0 & 91 & 67 & 01 & 0 & 8.4 \\
\hline & 43 & $21-27$ & 31.0 & 19.8 & 91 & 81 & 75 & 7 & 4 \\
\hline & 44 & $28-03$ & 30.4 & 17.5 & 86 & 75 & 0 & 0 & 6.6 \\
\hline \multirow[t]{4}{*}{ Nov-2013 } & 45 & $04-10$ & 30.2 & 16.8 & 87 & 73 & 0 & 0 & 9 \\
\hline & 46 & $11-17$ & 29.7 & 15.4 & 83 & 61 & 0 & 0 & 8.9 \\
\hline & 47 & $18-24$ & 31.4 & 17.2 & 90 & 71 & 0 & 0 & 8.8 \\
\hline & 48 & $25-01$ & 29.5 & 19.5 & 90 & 75 & 0 & 0 & 8 \\
\hline Dec-2013 & 49 & $02-08$ & 30.2 & 16.2 & 89 & 70 & 0 & 0 & 8.5 \\
\hline
\end{tabular}


transplanted during $28^{\text {th }} \mathrm{MW}$ has recorded significantly maximum plant height at harvest. This might be due to congenial climatic conditions for better seedling and further growth and development of the Kharif paddy crop. These results were in accordance with Saikia et al., (1989), Paraye and Kandalkar (1994), Rakesh and Sharma (2004) and Dileep et al., (2018).

Mean plant height was significantly influenced up to harvesting due to different varieties. The significantly maximum plant height was observed at harvest with the variety Phule Samruddhi $(87.5 \mathrm{~cm})$ over the rest of the varieties. This might be due to varietal characters, earlier same reported by Dileep et al., (2018), Suryavanshi (2015), Halimi et al., (2018) and Shende et al., (2020).

Interaction effect between transplanting times and different varieties of paddy was found significant in respect of the mean plant height of paddy shown in Table 2. Variety Phule Samruddhi when transplanted during $28^{\text {th }} \mathrm{MW}$ recorded significantly higher plant height at 15 DAT $(32.3$ $\mathrm{cm}), 30$ DAT $(51.6 \mathrm{~cm}), 45$ DAT $(67.8 \mathrm{~cm}), 60$ DAT $(84.7$ $\mathrm{cm}), 75$ DAT $(97.4 \mathrm{~cm}), 90$ DAT $(99.4 \mathrm{~cm}), 105$ DAT $(100$ $\mathrm{cm})$ and at harvest $(100.6 \mathrm{~cm})$ however it was at par with Indrayani transplanted during $28^{\text {th }} \mathrm{MW}$ at all the growth stages except at 30 and 45 DAT as well as with same variety transplanted during $26^{\text {th }} \mathrm{MW}$ at 15 and 30 DAT only.

\section{Correlation between weather parameters and plant height}

The correlation between parameters with growth characters shown in Table 4 and weekly weather meteorological data recorded during experiment period is presented in Table 3. Paddy variety Phule Samruddhi recorded maximum plant height due to varietal characters and weather conditions during that period.

The correlation between weather parameters and plant height revealed a significant negative correlation in case of maximum temperature from 30 DAT to harvesting, in bright sun hour from 15 DAT to harvesting and in case of GDD 30 DAT to 60 DAT. The Highly significant positive correlation found with T min 45 DAT, 60 DAT to at harvest, in RH-I 90 DAT and at harvest, in RH-II from 15 DAT to at harvest and in rainfall from 30 DAT to at harvest. The results found similar to Chandra et al., (2009).

\section{Effect on number of tillers plant ${ }^{-1}$}

Number of tillers plant ${ }^{-1}$ was significantly influenced due to different transplanting times at harvest presented in Table 1. The transplanting of paddy seedlings at $28^{\text {th }} \mathrm{MW}$ recorded the significantly higher number of tillers (16) over the rest of the transplanting times. The transplanting of paddy at $26^{\text {th }}$ MW performed second-best treatment to produce the significantly higher number of tillers (14) plant $^{-1}$ than $30^{\text {th }}$ $\mathrm{MW}$ and $32^{\text {nd }} \mathrm{MW}$. The lowest number of tillers (8) were observed when transplanting was done $32^{\text {nd }} \mathrm{MW}$. These results were in accordance with Rakesh and Sharma (2004), Akram et al., (2007), Kabir et al., (2014) and Singh et al., (2019).

The maximum number of tillers plant $^{-1}$ (17) was found with the variety Phule Samruddhi which was significantly superior over the rest of the paddy varieties. The variety Phule Radha recorded the significantly lower number of tillers plant ${ }^{-1}(8)$ than the remaining varieties. These findings were collaborative with the earlier reported by Suryavanshi (2015), Halimi et al., (2018) and Shende et al., (2020).

Interaction effects of paddy transplanting times and varieties were significantly influenced number of tillers plant ${ }^{-1}$ shown in Table 2. The transplanting of the variety Phule Samruddhi paddy in $28^{\text {th }} \mathrm{MW}$ ( $2^{\text {nd }}$ week of July) was recorded the highest number of tillers plant ${ }^{-1}(21)$ than the rest of treatment combinations while the lowest in variety Phule Radha in $32^{\text {nd }}$ MW (06).

\section{Correlation between weather parameters and number of tillers plant ${ }^{-1}$}

Correlation between parameters with growth characters presented in Table 4 and weekly weather meteorological data recorded during experiment period is presented in Table 3. The variety Phule Samruddhi recorded the maximum number of tillers plant ${ }^{-1}$ due to varietal characters and weather conditions during that period. The correlation between weather parameters and the number of tillers plant ${ }^{-1}$ revealed the significant negative correlation in the case of maximum temperature $\left(r=-0.630^{* \star}\right)$ and bright sunshine hour

Table 4: Correlation between weather parameters and growth attributing characters.

\begin{tabular}{|c|c|c|c|c|c|c|c|c|}
\hline \multirow{3}{*}{$\begin{array}{l}\text { Weather } \\
\text { parameter }\end{array}$} & \multicolumn{7}{|c|}{ Plant height $(\mathrm{cm})$ plant $^{-1}$} & \multirow{3}{*}{$\begin{array}{l}\text { Number of } \\
\text { tillers plant }\end{array}$} \\
\hline & \multicolumn{7}{|c|}{ Days after transplanting (DAT) } & \\
\hline & 15 & 30 & 45 & 60 & 75 & 90 & At harvest & \\
\hline $\mathrm{T} \max$ & -0.244 & $-0.617^{* *}$ & $-0.616^{\star *}$ & $-0.600^{* *}$ & -0.586 & $-0.604^{* *}$ & $-0.601^{* *}$ & $-0.630^{\star *}$ \\
\hline $\mathrm{T} \min$ & 0.146 & 0.114 & $0.449^{*}$ & 0.241 & $0.536^{*}$ & $0.574^{*}$ & $0.583^{*}$ & $0.586^{*}$ \\
\hline $\mathrm{RH}-\mathrm{I}$ & 0.293 & 0.276 & 0.223 & 0.006 & 0.153 & 0.496 & $0.583^{*}$ & $0.537^{\star}$ \\
\hline RH-II & $0.471^{*}$ & $0.662^{* *}$ & $0.637^{* *}$ & $0.614^{* *}$ & $0.592^{*}$ & $0.598^{*}$ & $0.564^{*}$ & $0.643^{* *}$ \\
\hline Rainfall & 0.362 & $0.644^{* *}$ & $0.643^{* *}$ & $0.571^{*}$ & $0.620^{* *}$ & $0.599^{*}$ & $0.580^{*}$ & $0.645^{\star *}$ \\
\hline GDD & -0.228 & $-0.542^{*}$ & $-0.496^{*}$ & -0.471 & -0.023 & -0.193 & 0.304 & -0.483 \\
\hline Bright sunshine $\mathrm{hr}$. & -0.619 & $-0.603^{* *}$ & $-0.606^{\star *}$ & $-0.573^{*}$ & $-0.573^{*}$ & $-0.574^{*}$ & $-0.570^{*}$ & $-0.612^{* *}$ \\
\hline Canopy temperature & -0.299 & 0.310 & -0.259 & -0.255 & -0.252 & -0.251 & -0.250 & -0.380 \\
\hline
\end{tabular}

*Significant at $5 \%$; ${ }^{* *}$ Significant at $1 \%$. 
Growth and Correlation with Weather Parameters as Affected by Transplanting Time and Different Varieties of Paddy...

$\left(r=0.612^{* *}\right)$. Significant positive correlation with $\mathrm{T}$ min, $\mathrm{RH}-$ I, RH-II and rainfall founded $r=0.586^{*}, r=0.537^{*}, r=0.643^{* *}$ and $r=0.645^{* *}$, respectively. The results found similar to Chandra et al., (2009).

\section{CONCLUSION}

Based on experiment findings it was concluded that transplanting time and different paddy varieties significantly influenced the growth attributing characters of paddy. Transplanting on $28^{\text {th }} \mathrm{MW}$ ( $2^{\text {nd }}$ week of July) resulted significantly maximum in plant height, number of tillers plant ${ }^{-1}$. The variety Phule Samruddhi recorded significantly higher plant height, number of tillers plant ${ }^{-1}$, Phule Samruddhi was found suitable under Vadgaon-Maval conditions. Among the interactions, the VDN-99-29 (Phule Samruddhi) variety of paddy was transplanted during $28^{\text {th }} \mathrm{MW}$ ( $2^{\text {nd }}$ week of July) favourably influenced growth attributing characters as compared to other interactions formed due to transplanting times and varieties. Transplanting of Phule Samruddhi on $28^{\text {th }} \mathrm{MW}$ ( $2^{\text {nd }}$ Week of July) was found ideal and climatically suitable for Vadgaon-Maval conditions. Correlation indicated that tmax i.e., maximum temperature, bright sun hour and growing degree days (GDD) showed significant and negative co-relationship with growth attributing characters of paddy, whereas tmin i.e., minimum temperature, $\mathrm{RH}-\mathrm{I}$ and $\mathrm{RH}-\mathrm{II}$ during the crop growing period showed positive and significant correlation with growth attributing characters of paddy.

\section{ACKNOWLEDGEMENT}

Authors sincerely thank the ARS, Vadgaon-Maval, TalukaMaval, District-Pune, Maharashtra, India for ease and smooth conduct of laboratory and experimental work and also thank to the College of Agriculture, Pune and MPKV, Rahuri for providing all the facilities to conduct research. Thanks, Dr. N.V. Kashid for initial review of manuscript.

\section{Conflict of interest: None.}

\section{REFERENCES}

Akram, H.M., Ali, A., Nadeem, M.A. and Iqbal, M.S. (2007). Yield and yield components of rice varieties as affected by transplanting dates. J. Agri. Res. 45(2): 105-111.

Bruns, H.A., Abbas, H.K., (2006). Planting date effects on Bt and Non-Bt corn in the mid-south USA. Agron. J. 98: 100-106.

Chandra, B.S., Reddy, T.D., Ansari, N.A. and Kumar, S.S. (2009). Correlation and path analysis for yield and yield components in rice (Oryza sativa L.). Agric. Sci. Digest. 29(1): 45-47.

Chowdhury, M.J.U., Hossain, S.M.A., Gaffer, M.A., Islam, M.A. (2000). Hill distribution an effective transplanting arrangement in the late Transplanted Aman rice. Bangladesh. J. Crop Sci. 11(1-2): 9-16.
Dileep, K., Pasupalak, S. and Baliarsingh, A. (2018). Predicting the effect of weather parameters on yield performance of rice varieties (Oryza sativa L.) under different planting condition during Kharif season. The Pharma Innova. J. 7(11): 257-262.

Grover, D.K. (2013). Economic profile of rice cultivation in Punjab. Indian J. Agric. Res. 47(4): 335-340.

Halimi, E.S., Haryadi, P., Kholiq, A., Saputra, D. and Faradibta, A.F. (2018). Selection and field evaluation to increase yield and quality of several black rice accessions. Indian J. Agric. Res. 52(3): 264-270.

Islam Ajma. (1986). Review of agronomic research on rice and its future strategy. Adv. Agron. Res. Bangladesh. 1: 1-19.

Kabir, M.M., Naher, U.A., Panhwar, Q.A., Shamshuddin, J. and Khan, F.H. (2014). Effect of transplanting dates on growth and yield of inbred and hybrid rice varieties grown during rainfed season in Bangladesh. The Philippine Agril. Scientist. 97(4): 347-354.

Panse, V.G. and Sukhamate, P.V. (1967). Statistical Methods for Agricultural Workers, ICAR, New Delhi. 361.

Paraye, P.M. and Kandalkar, V.S. (1994). Effect of seedling age on long-duration rain fed varieties of rice under delayed transplanting. Indian J. agric. Sci. 64(3): 187-188.

Patel, A.R., Patel, M.L., Patel, R.K. and Mote, B.M. (2019). Effect of different sowing date on phenology, growth and yield of rice- A review. Plant Archives. 19(1): 12-16.

Rakesh, K. and Sharma, H.I. (2004). Effect of dates of transplanting and varieties on dry matter accumulation, yields attributes and yields of rice (Oryza sativa L.). Himachal J. Agric. Res. 30(1): 1-7.

Saikia, L., Chandra, K. and Mahanta, T.C. (1989). Performance of late transplanting rice in Assam. Intl. Rice Res. News. 14(1): 21

Shende, S.M., Hasure, R.R., Gajbhiye, P.N., Gedam, V.B. and Shinde, R.H. (2020). Response of dry seeding of Kharif paddy (Oryza sativa L.) Varieties to different fertilizer levels with respect to growth characters. Inter. J. Chemi. Stud. 8(6): 1272-1277.

Singh, K., Singh, Dhillon, B. and Singh Sidhu A. (2019). Effect of different transplanting dates on productivity and water expense efficiency in rice (Oryza sativa L.). Int. J. Curr. Microbiol. App. Sci. 8(5): 1480-1486.

Suryavanshi, P.K. (2015). Performance of summer paddy varieties under fertilizer levels in relation to weather parameters. M.Sc. (Agri). Thesis. MPKV, Rahuri.

Virdia, H.M. and Mehta, H.D. (2009). Integrated nutrient management in transplanted rice (Oryza sativa L.). J. Rice Res. 2(2): 99-104.

Yoshida, S. (1993). Rice, Symposium on potential productivity of field crops under different environment. International Rice Research Institute, UK. p. 103-129. 